\title{
The Mediating Role of Psychological Flexibility in Explaining Authenticity and Life Satisfaction with Alexithymia
}

\author{
Sena Karakuş * \\ Faculty of Education, Psychological Counseling and Guidance, Mersin University, Mersin, \\ Turkey \\ ORCID: 0000-0003-3156-6958 \\ Sinem Evin Akbay \\ Faculty of Education, Psychological Counseling and Guidance, Mersin University, Mersin, \\ Turkey \\ ORCID: 0000-0001-6189-1896
}

\begin{tabular}{ll}
\hline \hline Article history & Within the scope of this study, the relationships among alexithymia, \\
Received: & psychological flexibility, authenticity and life satisfaction of individuals \\
10.06 .2020 & were investigated. In addition, the possible meditating role of \\
Received in revised form: & psychological flexibility on the relationships among alexithymia, \\
09.03 .2021 & authenticity and life satisfaction were investigated. The research model \\
Accepted: & is the relational screening model, which is one of the descriptive models \\
12.03 .2021 & that aims to examine the mediating role of psychological flexibility in \\
Key words: & the relationships among individuals' alexithymia, authenticity and life \\
Alexithymia, & satisfaction. As the data collection tools, "Personal Information Form", \\
Authenticity, & "Toronto Alexithymia Scale (TAS-20)", "Authenticity Scale", \\
Life satisfaction, & "Psychological Flexibility Scale" and "Life Satisfaction Scale" were \\
Psychological flexibility & used. The sampling group of the study was composed of 702 adult \\
& individuals between the ages of 18 and 67Whilst analysing the data, \\
& SPSS 22 Package Program was used to highlight the relationships \\
& between variables (Pearson correlation coefficient) and mediation test. \\
& In the study, Bootstrap analysis and Sobel test were used to measure the \\
& statistical significance of the mediating effects of the model. According \\
& to the research findings, while there was a significant negative \\
& relationship between alexithymia and psychological flexibility variables \\
& and authenticity and life satisfaction variables, a positive significant \\
& relationship was found among psychological flexibility, authenticity and \\
& life satisfaction. According to the mediation test, psychological \\
& flexibility had a partial mediating role in the relationships among \\
& alexithymia, life satisfaction and authenticity. Alexithymia explained \\
& $52 \%$ of authenticity and $21 \%$ of life satisfaction through psychological \\
flexibility. The present article discusses the abovementioned research \\
results within the framework of the relevant literature, and suggestions \\
are made accordingly.
\end{tabular}

*Correspondency: senakarakus@mersin.edu.tr 


\section{Introduction}

As a scientific field, the main purpose of Psychology is to understand and explain the behavior of the individual. The emotions of an individual are as important as the thoughts that affect the individual's behavior. Emotion is a personal sense that occurs as a consequence of the fact that individuals are aware of the stimulus in their environment, and that they are able to evaluate them (Frijda 2008; Tarhan, 2009). As individuals, who are aware of their emotions, will establish better relationships in quality throughout their lives, their social relationships will be positively affected (Kuzucu, 2006), and their life satisfaction levels will also increase (Kemerli \& Çelik, 2015). It is a well-known fact that the high emotional awareness level of individuals provides information about their current situation and helps them make rational decisions for the situations they will experience later on (Feldman-Barret, Gross, ConnerSristensen \& Benvenuto, 2001).

Expressing their emotions together with emotional awareness can lead to an understanding of the individual as to with whom they are communicating. It may also direct individuals to empathize and regulate their behavior accordingly (Beck, 2001). Therefore, individuals should not show alexithymic characteristics within the framework of empathic understanding. It is like a precondition; in other words, it can be said that the individual needs to be aware of their emotions and express them. Individuals, who do not show alexithymia, will also have high selfconfidence. In that sense, individuals can lead a more authentic life by accepting themselves as they are and not being dependent on people around them (Yalçın, 2010).

The concept of psychological flexibility means that individuals are aware of their emotions and express them without changing their own feelings and thoughts. The individuals with psychological flexibility can focus on the moment, and they have values that they behave in line with. Also, the concept of psychological flexibility is the ability to match the emotion of the individual with the situation he / she is in (Fujimura \& Okanoya, 2012). According to another definition, psychological flexibility is the ability of an individual to experience his or her internal experiences (such as emotions, thoughts and bodily sensations) as they are without interpreting, changing or trying to reduce these (Aktepe, 2016). The individual with psychological flexibility is eager to contact these experiences instead of preventing, changing and controlling unwanted or compelling life experiences. When individuals are in contact with these life experiences, they can determine unique values, lead a more authentic life and exhibit behaviors accordingly (Fledderus, Bohlmeijer, Smit, \& Westerhof, 2013). Thus, not only life quality levels of the individuals but also levels of life satisfaction are higher (Harris, 2016). Individuals with a high level of psychological flexibility are able to regulate their emotions successfully when necessary, by being aware of their emotions (Uygur, 2018). Related research showed that a significant relationship was found between difficulty in emotion regulation, lack of emotional awareness and rejection of emotions (Gratz \& Roemer, 2004). Furthermore, individuals with alexithymic characteristics do not accept themselves and continue their lives by acting like an autopilot as they tend to live dependently (Çeçen, 2015). For this reason, it is thought that individuals with alexithymia may have psychological rigidity.

Individuals, who do not have alexithymic features and who have high psychological flexibility, may continue their lives more authentically. Authenticity is the concept for self-expression and behaviors that are consistent with the values, desires and feelings of the individual (Harter, 2002). Considering the fact that authentic living is the consistency between feelings, thoughts and behaviors (Wood, Linley, Maltby, Balıousis, \& Joseph, 2008), these concepts are thought to be related to each other. Authenticity is very important since it means that the individual can express himself to others in an open and honest way and can live his true self (Heppner vd. 
2008; Lopez \& Rice, 2006). Individuals, who have high emotional awareness, can express their emotions and have psychological flexibility. Hence, they can lead a more authentic life, and their life satisfaction can increase accordingly. Therefore, the awareness of individuals about these concepts is very important in terms of their effective communication and life satisfaction (Y1ldırım, 2017). On the other hand, individuals with alexithymic characteristics and psychological rigidity cannot lead an authentic life and cannot get satisfaction from life because they will experience psychological problems (Yavuzer, 2000). The authenticity of the individual is key in terms of his / her mental health, whereas being not authentic in order to avoid pressure, coercion or punishment causes psychiatric disorders (İlhan \& Özdemir, 2013). In that sense, authenticity should be developed and demonstrated under any circumstances (Akbay, 2015).

Kernis and Goldman (2006) pointed out that authenticity is a structure with four interrelated components. The authors stated that these components are awareness, neutrality, authentic behavior and relational authenticity. The awareness component is the knowledge and acceptance of one's wishes, feelings, thoughts and needs, while the neutrality component is the ability to express the positive and negative aspects of the individual without distorting or exaggerating. Another component, authentic behaviour, means the ability to act according to one's own wishes, values and judgments, not for anyone else, and the last component, relational authenticity, is the ability to be sincere and open in one's relationships.

Regarding the components of authenticity, it can be said that authenticity may be related to emotional awareness and psychological flexibility. Much emphasis is attached on emotional awareness as well as psychological flexibility by accepting emotional thoughts in the awareness component. In the component of authentic behavior, it is emphasized that the individual has values and can act accordingly. Then, it has a coincidence with the behavioral dimension of psychological flexibility in line with values. In addition, individuals, who realize the environment, the people around them, and most importantly, their inner world, tend to behave with their true selves by adapting to life (Dökmen, 2000). Based on this claim, it is possible to assert the idea that it will be more authentic when individuals realize their own feelings and thoughts.

Emotional awareness along with mental and emotional acceptance concepts integrate life as a whole with its positive and negative aspects. Therefore, they enable the individual to enjoy life by increasing his personal power against the uncontrollable parts of their lives (Wong, 2015). The purpose herein, which motivates all individuals, is, in short, to try to get satisfaction from life. Life satisfaction is felt when there is a harmony between the life that the individual has and that he / she wants to be in. It is observed that individuals with high emotional awareness have higher life satisfaction, and they have the ability to cope with stress related events they experience (Swinkels \& Giuliano, 1995). Taking the individual's past events, situations they encountered and expectations for their future into consideration, it is possible to determine their emotions (Cüceloğlu, 2005), and emotional awareness of the individual are vital for their quality of life (Özen, Bez, Arı, \& Özkan 2010). Awareness of the emotional state experienced is regarded as a coping mechanism for the individual to express his / her feelings, and thus the individual can become open to experiences. Much as noticed and expressed emotions are sources of motivation for the lives of individuals (Dökmen, 2000), life satisfaction may also decrease if the individual shows alexithymic characteristics (Myers, Sweeney, \& Witmer, 2000).

It is considered that the present research will provide a comprehensive literature research on 
the concepts of alexithymia, psychological flexibility, life satisfaction and authenticity, and it will shed light onto more ideas for future research. There is no study in the literature that examines the relationship of these concepts among each other and tries to measure the mediation effect. In addition, since the previous studies were generally conducted with university students, the sample group was expanded with this study by adding adult individuals to the group.

Individuals may encounter some problems while continuing their lives, and this situation causes them to experience various negative emotions. It is thought that the ability of individuals to recognize their emotions in the face of situations or events they encounter, evaluation of the situations realistically, and the way they explain events are crucial in terms of the individual's quality of life and life satisfaction. Individuals, who are not aware of their emotions, also have problems in taking responsibility and decision-making processes in their lives (Gün, 2007; Koçak, 2002). It is also asserted that the low level of alexithymia in the psycho-social process of adults will increase life satisfaction. Considering the fact that individuals with awareness are individuals who can make healthy decisions and take over the responsibility of them, the tendency of individuals to live authentically will increase in this way (Greenberg, 2006).

So as to make individuals develop a healthy personality, they need to be aware of their own deficiencies, inadequacies, feelings and thoughts and accept them without changing them (being psychologically flexible). When this does not happen, the individual moves away from their true self, which means that he cannot be authentic, and this results in the person's inability to get satisfaction from life (Togay, 2016). For this reason, it is thought that this research will contribute to the studies on the importance of alexithymia, psychological flexibility, life satisfaction and authenticity for the lives of individuals by providing data on these concepts.

In fact, it is thought that the concepts of alexithymia, psychological flexibility, authenticity and life satisfaction may be related to each other. In this direction, the aim of this study is to examine the mediating effect of psychological flexibility on the relationships among alexithymia, authenticity and life satisfaction for adults. For this purpose, the research hypotheses are as follows:

(1) There is an indirect and negative effect through psychological flexibility in the relationship between individuals' alexithymia levels and their authenticity.

(2) There is an indirect and negative effect through psychological flexibility in the relationship between individuals' alexithymia levels and their life satisfaction.

\section{Method}

\section{Research Model}

The model of the study is a relational study, one of the descriptive models that aims to examine the mediating role of psychological flexibility in explaining individuals' authenticity life satisfaction with alexithymia. Relational Screening Model aims to determine the existence and degree of the relationship between variables (Karasar, 2005). The mediation model created for this research in line with the theoretical background is shown in Figure 1. 


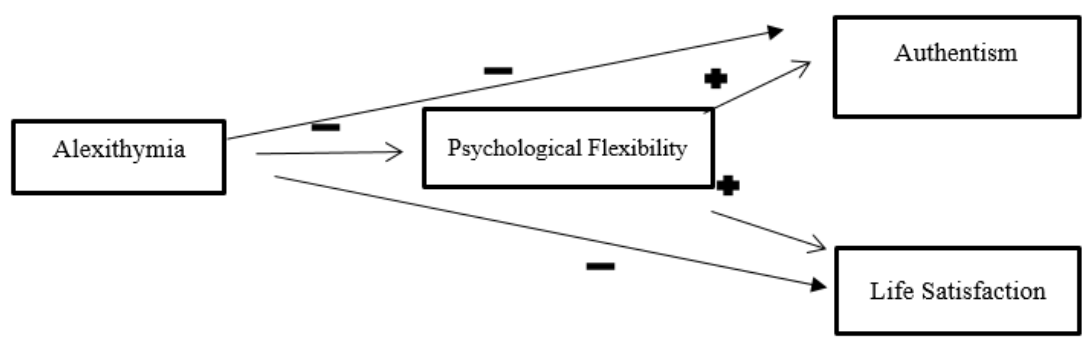

Figure 1. Mediation Model of the Research

\section{Universe and Sample of the research}

Participants that make up the sample of the study were selected in two stages. In the first stage, criterion-based sampling technique was used. The criterion is the 'adult individual'. In the second stage, these adult participants were reached using an easily accessible sampling method. The participants were 784 people and 82 of the individuals were excluded. When the extreme value analysis was identified as an outlier, the study continued with the final 702 participants. There are many criteria regarding the size of the number of observations. Some of them put forward that the sample size should be at least 200 (Guilford, 1954), while Tabachnick and Fidell (2013) state that this number should be at least 300. Demographic variables of the sample are shown in Table 1.

Table 1. Demographic Variables of the Participants

\begin{tabular}{|c|c|c|c|}
\hline Variables & & $\mathbf{N}$ & $\%$ \\
\hline \multirow[t]{2}{*}{ Gender } & Female & 488 & $\% 69,5$ \\
\hline & Male & 214 & $\% 30,5$ \\
\hline \multirow[t]{3}{*}{ Relationship status } & Have a relationship & 287 & $\% 40,8$ \\
\hline & Not related & 159 & $\% 22,7$ \\
\hline & Married & 256 & $\% 36,5$ \\
\hline \multirow[t]{5}{*}{ Level of education } & Primary school & 4 & $\% 0,5$ \\
\hline & Middle School & 4 & $\% 0,5$ \\
\hline & High school & 219 & $\% 31,3$ \\
\hline & University & 359 & $\% 51,2$ \\
\hline & Graduate & 116 & $\% 16,5$ \\
\hline \multirow{3}{*}{$\begin{array}{l}\text { Perceived } \\
\text { Level }\end{array}$} & Low & 39 & $\% 5,5$ \\
\hline & Middle & 589 & $\% 84,0$ \\
\hline & High & 74 & $\% 10,5$ \\
\hline \multirow[t]{2}{*}{ Working condition } & Working & 347 & $\% 49,4$ \\
\hline & Not working & 355 & $\% 50,6$ \\
\hline
\end{tabular}

\section{Data Collection Tools}

\section{Personal Information Form}

The "Personal Information Form" prepared by the researcher includes information about the participants' gender, age, relationship status, education level, perceived socio-economic level and job status.

\section{Toronto Alexithymia Scale}

It was developed by Bagby, Taylor, and Parker (1994). The scale was adapted to Turkish by Güleç, Köse, Güleç, Çitak, Evren, Borckardt, and Sayar (2009). It has three main dimensions: items for difficulty in recognizing emotions $(1,3,6,7,9,13$ and 14), items for 
difficulty in expressing emotions $(2,4,11,12$ and 17) and items for operational (operational) thinking $(5,8,10,15,16,18,19$ and 20) that are prepared in accordance with the original scale. The Cronbach alpha coefficients of the scale are $.80, .57$ and .63 for the sub-dimensions. The total scale is .78. In this study, Cronbach's alpha coefficients were found to be .86 for difficulty in recognizing emotion, .69 for difficulty in expressing emotions, .50 for operational thinking, and .83 for the total scale.

\section{Psychological Flexibility Scale}

The Cronbach $\alpha$ internal consistency coefficient of the scale developed by Francis, Dawson and Golijani-Moghaddam (2016) was found to be .90 for openness to experience subscale, .87 for behavioral awareness subscale, .90 for life subscale in line with values, and .91 for total scale. The scale, which was adapted to Turkish context by Karakuş and Akbay (2020), consists of 28 items, and it is a 7-point Likert ( $1=$ strongly disagree; $7=$ totally agree $)$ type. The scale has five sub-dimensions: instant ( 7 items), acceptance (5 items), contextual self ( 3 items), dissociation ( 3 items), and behavior in line with values (10 items). The Cronbach alpha reliability coefficient of the scale is .79. Considering the reliability of the sub-dimensions, it can be said that the dimension of behavior in the direction of value is .84; being in the moment is .60; accepting is .72; contextual self is .73, and separation is .59 (Karakuş \& Akbay, 2020) respectively. For the present study, the Cronbach alpha coefficients according to the subdimensions are .70 for contextual self. The coefficient is .87 for value and value-based behaviour. Also, the other coefficient levels are: .56 for being at the moment, .71 for acceptance, .51 for dissociation, and .77 for the whole scale. According to Büyüköztürk (2015), a reliability coefficient above .50 is considered reliable.

\section{Authenticity Scale}

The Authenticity Scale (AQ) was developed by Wood et al. (2008). It was later adapted Turkish by İlhan and Özdemir (2013). It is a 7-point Likert type scale, and it consists of 12 items. The scale also includes sub-dimensions of self-alienation $(2,7,10,12)$, acceptance of external influence $(3,4,5,6)$, and authentic life $(1,8,9,11)$. The scores that can be obtained from the scale range from 12 to 84 . Although there is no reverse scoring item, authenticity score can be obtained when the scores of self-alienation and acceptance of external ethics are removed from the authentic life dimension. The Cronbach alpha coefficients of the original form of the scale were found as .78 for the self-alienation dimension, .78 for acceptance of external influence dimension and .69 for the authentic life dimension, respectively, according to the sub-dimensions. Furthermore, test-retest reliability coefficients were found to change between .85 and .91 (Wood et al., 2008). The Cronbach Alpha internal consistency coefficients for the adaptation study of the scale were .79 for the first dimension, .67 for the second dimension and .62 for the final dimension, respectively (İlhan \& Özdemir, 2013). For this study, Cronbach's alpha coefficients were found to be .86 for self-alienation, .87 for accepting external influence, . 72 for authentic life, and .73 for the whole scale, according to the sub-dimensions.

\section{Life Satisfaction Scale}

The scale was developed by Diener, Emmons, Larsen, and Griffin (1985). It was adapted to Turkish by Dağlı and Baysal (2016). It is a five-point Likert-type scale and consists of 5 items. The consistency between English and Turkish scales was calculated as .92. From the scale, 7 points and below indicate low life satisfaction, 8-12 points indicate medium, and 13 points and above indicate high life satisfaction. The Cronbach Alpha internal consistency coefficient of the scale was .88, and test-retest reliability was .97 . As a result of the validity and 
reliability analyses, it was identified that the scale is a valid-reliable tool (Dağlı \& Baysal, 2016). In this study, the internal consistency reliability coefficient of the scale was found to be .85 .

\section{Data Analysis}

In order to analyze the data, the SPSS 22 Package Program was used to highlight the relationship between variables (Pearson correlation coefficient) and mediation test. In the study, the Least-Squares Standard Approach Regression Analysis and Bootstrap Method were used in order to scale the statistical significance of the mediating effects of the model. The purpose of the bootstrapping method is to create a larger data set by resampling from the data set; thus, the aim is to predict the indirect effect (Takma \& At1l, 2006; Preacher \& Hayes, 2008).

When the data related to kurtosis and skewness values for normality test are considered, it can be said that the values are like these; skewness $=.284$, kurtosis $=-.261$ for alexithymia variable, skewness $=-.066$, kurtosis $=.466$ for psychological flexibility variable, skewness $=-.442$, kurtosis $=.287$ for authenticity variable, kurtosis $=-.175$, skewness $=-.191$ for life satisfaction variable. Tabachnick and Fidell (2013) stated that these coefficients should be between -1.5 and +1.5. In this research, Bootstrapping analysis was performed by using "Model 4" with SPSS PROCESS Macro system. In this study, the statistical significance of the direct and indirect effects of the independent variable on the dependent variable was examined in 5000 bootstrap samples. The Sobel test was used to determine whether the mediating variable was significant. The independent variable of the study is alexithymia, the mediator variable is psychological flexibility, and the dependent variables are authenticity and life satisfaction. The significance level in the study was found as.01.

\section{Findings}

Taking the abovementioned items into account, findings related to the mediating role of psychological flexibility in the relationship between alexithymia, life satisfaction and authenticity of adults participating in the study were considered. The findings were explained according to the explanations and assumptions about the model, and the model was tested statistically.

\section{The Relationships among Alexithymia, Psychological Flexibility and Authenticity}

In the analysis phase, firstly, the relationships among variables have been examined, and the descriptive statistics and Pearson correlation coefficients of the variables in the hypothesis model are given in Table 1.

Table 2. Descriptive Statistics of the Variables and Pearson Correlation Coefficient Values

\begin{tabular}{llllll}
\hline Variables & $\bar{X}$ & $\mathrm{Sd}$ & 1 & 2 & 3 \\
\hline 1.Alexithymia & 47.81 & 9.78 & 1 & & \\
2. Psychological Flexibility & 134.07 & 15.58 & $-.58^{* *}$ & 1 & \\
3. Authenticity & 63.72 & 11.79 & $-.62^{* *}$ & $.65^{* *}$ & 1 \\
\hline
\end{tabular}
$* * p<.01$

When Table 2 is examined, it is seen that the correlation coefficients between the variables are -.58 between alexithymia and psychological flexibility, -.62 between alexithymia and authenticity, and .65 between psychological flexibility and authenticity. Significant negative correlations were found between alexithymia, psychological flexibility and authenticity. On the other hand, in a positive direction, there is a psychological flexibility and authenticity 
correlation.

\section{The Relationships among Alexithymia, Psychological Flexibility and Life Satisfaction}

In the analysis phase, firstly, the relationships between variables have been examined, and the descriptive statistics and Pearson correlation coefficients of the variables in the hypothesis model are given in Table 2.

Table 3. Descriptive Statistics of Variables and Pearson Correlation Coefficient Values

\begin{tabular}{llllll}
\hline Variables & $\overline{\mathrm{X}}$ & $\mathrm{Sd}$ & 1 & 2 & 3 \\
\hline 1.Alexithymia & 47.81 & 9.78 & 1 & & \\
2. Psychological Flexibility & 134.07 & 15.58 & $-.58^{* *}$ & 1 & \\
3. Life satisfaction & 16.18 & 3.56 & $-.36^{* *}$ & $.43^{* *}$ & 1 \\
\hline
\end{tabular}
$* * p<.01$

When Table 3 is examined, it is seen that the correlation coefficients among the variables are .58 between alexithymia and psychological flexibility, -.36 between alexithymia and life satisfaction, and .43 between psychological flexibility and life satisfaction. There is a negative relationship between alexithymia and psychological flexibility and life satisfaction. Furthermore, significant positive correlations were found between psychological flexibility and life satisfaction.

\section{The Mediating Role of Psychological Flexibility in the Relationship between Alexithymia and Authenticity}

The research findings examining the mediating role of psychological flexibility in the relationship between alexithymia and authenticity are illustrated in Figure 2.

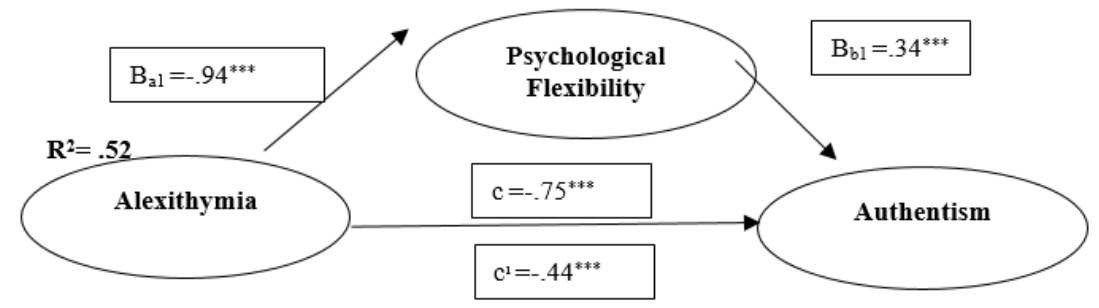

Figure 2. The Mediating Role of Psychological Flexibility in the Relationships among Alexithymia, Authenticity and Unstandardized Beta Values $* * * \mathrm{p}<.001$

As it is illustrated in Figure 2, the total effect of alexithymia on authenticity $(\mathrm{c}=-.75, \mathrm{SH}=.04$, $\mathrm{t}=-21.12, \mathrm{p}<.001)$ is significant. In addition, the direct effect of alexithymia on psychological flexibility $(\mathrm{B}=-.94, \mathrm{SH}=.05, \mathrm{t}=-19.23, \mathrm{p}<.001)$, which is the mediator variable of the research, is significant. Furthermore, the direct effect of psychological flexibility on authenticity $(\mathrm{B}=.34, \mathrm{ST}=.03, \mathrm{t}=13.61, \mathrm{p}<.001)$ is significant.

When psychological flexibility, the mediator variable of the research with alexithymia, was taken simultaneously to the analysis, the direct coefficient effect of alexithymia on authenticity decreased; however, the significance value remained the same (c ' $=-.44, \mathrm{SH}=.04, \mathrm{t}=-.11 .19$, $\mathrm{p}<.001)$. In line with this result, it can be said that psychological flexibility plays a partial mediating role between alexithymia and authenticity. It can be also claimed that the model is statistically significant $(\mathrm{F}(2-699)=374.48, \mathrm{p}<.001)$ and explains $52 \%$ of the authenticity. 
The values regarding the effects of alexithymia, psychological flexibility and the variables of the authenticity model in the study are illustrated in Table 3 as follows:

Table 4. The Effects between Variables in Alexithymia, Psychological Resilience and Authenticity Model

\begin{tabular}{|c|c|c|c|c|c|c|}
\hline \multirow[b]{2}{*}{ Effects } & \multirow[b]{2}{*}{ Point Estimation } & \multicolumn{3}{|c|}{ Product of coefficients } & \multicolumn{2}{|c|}{$\begin{array}{l}\text { Bootstrapping } \\
\% 95 \mathrm{BCa} \text { Confidence Interval }\end{array}$} \\
\hline & & $\overline{\mathrm{SH}}$ & $\mathrm{Z}$ & $p$ & Low & High \\
\hline Indirect Effect & -.3136 & .0314 & -11.1011 & $.000 * * *$ & -.3803 & -.2567 \\
\hline Total Effect & -.7523 & .0356 & & & -.8222 & -.6823 \\
\hline Direct Effect & -.4387 & .0392 & & & -.5156 & -.3618 \\
\hline
\end{tabular}

Table 4. shows the results in which the study was examined on 5000 bootstrap samples. The estimates were evaluated at $95 \%$ confidence interval and corrected by removing the bias error. As it is illustrated in Table 3, the indirect effect of alexithymia on authenticity through psychological flexibility (difference between total and direct effect) is statistically significant (point estimate $=-.3136$ and $95 \%$ BCa CI $(-.3803),-2567])$. Thus, it has been found out that psychological flexibility plays a partial mediating role in the relationship between alexithymia and authenticity.

\section{The Mediating Role of Psychological Flexibility in the Relationship between Alexithymia and Life Satisfaction}

The research findings examining the mediating role of psychological flexibility in the relationship between alexithymia and life satisfaction are given in Figure 3.

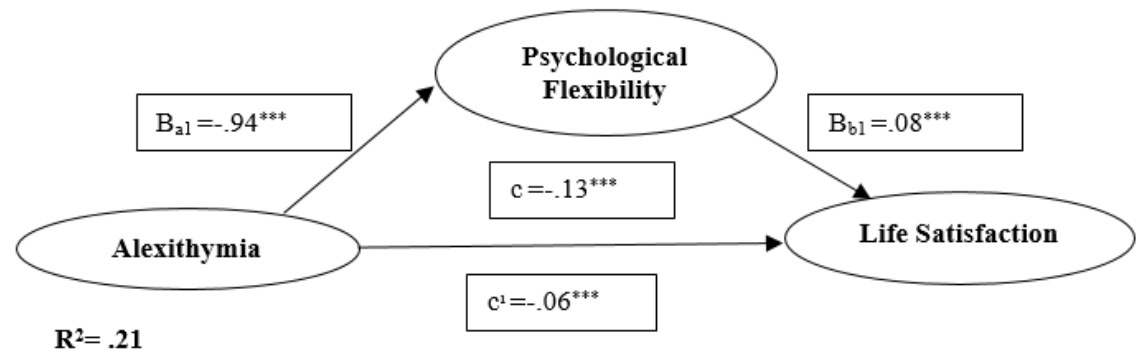

Figure 3. The Mediating Role of Psychological Flexibility in the Relationship between Alexithymia and Life Satisfaction and Unstandardized Beta Values *** $\mathrm{p}<.001$

As seen in Figure 3, the total effect of alexithymia on the life satisfaction variable (c $=-.13, \mathrm{SH}$ $=.01, \mathrm{t}=-10.42, \mathrm{p}<.001)$ is significant. In addition, the direct effect of alexithymia on psychological flexibility $(\mathrm{B}=-.94, \mathrm{SH}=.05, \mathrm{t}=-19.23, \mathrm{p}<.001)$, which is the mediator variable of the research, is significant. Furthermore, the direct effect of psychological flexibility on life satisfaction $(\mathrm{B}=.08, \mathrm{ST}=.01, \mathrm{t}=7.94, \mathrm{p}<.001)$ is significant. When psychological flexibility, the mediator variable of the research with alexithymia, was taken simultaneously to the analysis, the direct effect coefficient of alexithymia on satisfaction with life decreased; however, the significance value remained the same $\left(\mathrm{c}^{\prime}=-.06, \mathrm{SH}=.02, \mathrm{t}=-4.12, \mathrm{p}<.001\right)$. According to this result, it is possible to claim that psychological flexibility plays a mediating role between alexithymia and life satisfaction. In addition, it is seen that the model is statistically significant $(\mathrm{F}(2-699)=90.81, \mathrm{p}<.001)$ and explains $21 \%$ of the authenticity.

The values related to the effects among the variables of alexithymia, psychological flexibility and life satisfaction model in the study are given in Table 4. 
Table 5. The Effects among Variables in Alexithymia, Psychological Flexibility and Life Satisfaction Model

\begin{tabular}{lllclll}
\hline & & \multicolumn{3}{c}{ Product of coefficients } & \multicolumn{3}{c}{ \% 95 BCa Confidence Interval } \\
\cline { 3 - 7 } Effects & Point Estimation & SH & Z & $p$ & Low & igh \\
Indirect Effect & -.0710 & .0099 & -7.3386 & $.000 * * *$ & -.0901 & $i 17$ \\
Total Effect & -.1336 & .0128 & & & -.1587 & -.1084 \\
Direct Effect & -.0626 & .0152 & & & -.0924 & -.0328 \\
\hline
\end{tabular}

$\mathrm{N}=702, \mathrm{k}=5000, * \mathrm{p}<.05, * * \mathrm{p}<.01, * * * \mathrm{p}<.001$ BCa: 5000 bootstrap samples bias corrected and accelerated

Table 5. displays the results where the study was examined on 5000 bootstrap samples. The estimates were evaluated at $95 \%$ confidence interval and corrected by clearing the bias error. Considering the data in Table 4, the indirect effect of alexithymia on life satisfaction through psychological flexibility (c-c ') is statistically significant (point estimate $=-.0710$ and $95 \% \mathrm{BCa}$ CI [-. 0901, -.0517]). Hence, it has been found out that psychological flexibility plays a partial mediating role in the relationship between alexithymia and life satisfaction.

\section{Discussion and Suggestions}

In this section, the findings regarding the mediating role of psychological flexibility in the relationships among alexithymia, authenticity and life satisfaction are discussed and interpreted by taking the previous studies on the topic into account.

\section{Discussion and Interpretation of Findings Regarding the Relationships among Alexithymia, Psychological Flexibility and Authenticity}

In the light of present research findings, it can be asserted that alexithymia explains $52 \%$ of authenticity through psychological flexibility. In other words, alexithymia negatively predicts authenticity through psychological flexibility. When psychological flexibility, the mediator variable of the research, was simultaneously included in the analysis, the direct effect coefficient of alexithymia on authenticity decreased; however, the significance value remained the same $\left(\mathrm{c}^{\prime}=-.44, \mathrm{SH}=.04, \mathrm{t}=-.11 .19, \mathrm{p}<.001\right)$.

In this way, the first hypothesis of the study is that there is an indirect and negative effect on the relationship between the alexithymia levels of individuals and their authenticity through psychological flexibility. In other words, individuals who do not show alexithymic characteristics become psychologically more flexible, and therefore they lead a more authentic life. This result is also supported by other research results. Individuals who do not show an alexithymic feature, that is, can express their emotions by being aware of their emotions, are psychologically more flexible (Denckla, Consedine, Chung, Stein, Roche \& Blais 2018), and individuals with psychological flexibility can live more authentically (Fledderus et al., 2013; Neff \& Suizzo, 2006). These results are in line with the studies of İlhan and Özdemir (2013) and Kuyumcu and Kabasakoğlu (2018), who state that individuals who realize positive and negative emotions can lead a more authentic life. Studies reporting that there is a positive relationship between emotional expression (disclosure) and authenticity (Brunell et al., 2010; Neff \& Suizzo, 2006) also confirm the result of this research. In this way, individuals can exhibit more functional behavior. The reason is that if an individual wants to have a high psychological flexibility, the first step in the psychological flexibility process is to be aware of the emotions and thoughts. Thus, such an individual accepts these without trying to change 
them.

People with psychological flexibility indeed accept compelling feelings and thoughts instead of rejecting them, and they can live authentically by determining their own values and behaving accordingly (Fledderus et al., 2013). In this way, individuals with psychological flexibility can lead a more authentic life. In other words, they live according to their own values, and they do not live according to someone else's wishes. It can be said that the individual who can express his "real self" by accepting his feelings and thoughts leads an authentic life. In light of these ideas, it can be said that alexithymia levels can explain authenticity through psychological flexibility.

It can also be said that the results of the research (Albal, 2019; Uygur, 2018) stating that there is a positive relationship between emotional schemas (Leahy, 2006) and psychological flexibility, which are the process of noticing, perceiving, interpreting and coping with emotions, are also in line with the results of the research.

Baron and Kenny (1986) stated that the following conditions must be valid in order to mention mediation fully:

(1) The argument must affect the mediator.

(2) The independent variable should directly affect the dependent variable.

(3) The independent variable must affect the dependent variable indirectly through the mediating variable.

(4) As a result, the indirect effect of the independent variable on the dependent through the mediating variable should be less than the direct effect.

(5) When the effect is controlled, if the independent variable has no effect, full mediation is mentioned. Otherwise, if the level of indirect effect is lower than the direct effect, partial mediation can be mentioned.

While the direct effect of alexithymia on authenticity is $c=-.75$, its effect on authenticity through psychological flexibility is c '= -.44'. In line with the opinion of Baron and Kenny (1986), it can be said that psychological flexibility plays a partial mediating role in the relationship between alexithymia and authenticity since the significance value remains the same, but the effect coefficient is reduced. Since it is a partial mediation, it can be said that it may affect alexithymia and authenticity relationship in other variables other than psychological flexibility.

Along with the tests offered by Baron and Kenny for mediation, the bootstrap model of Sobel and Preacher \& Hayes can also be used (Y1lmaz \& Illhan Dalbudak, 2018). The Sobel test result $(\mathrm{Z}=-11.1010 ; \mathrm{p}=.000)$ confirms that there is a mediation role of psychological flexibility in the mediator role model for the relationship between alexithymia and authenticity.

All in all, it can be said that the bootstrap model of Preacher and Hayes (2008) gives the mean estimation, standard error estimate and BootLLCI and BootULCI values for indirect effect in 5000 bootstrap samples at $95 \%$ confidence interval. The indirect effect test is not meaningful if it contains zero between the BootLLCI and BootULCI values. In light of research findings, it can be said that there is a mediation in the relationship between alexithymia and authenticity, since there is no " 0 " between these values in the psychological flexibility mediator role model. 


\section{Discussion and Interpretation of Findings Related to the Relationships of Alexithymia, Psychological Flexibility and Life Satisfaction}

Another finding of the study is that alexithymia explains $21 \%$ of life satisfaction through psychological flexibility. According to this finding, alexithymia predicts life satisfaction at a low level and in a negative way through psychological flexibility. When psychological flexibility, the mediator variable of the research, was simultaneously included in the analysis, the direct coefficient effect of alexithymia on life satisfaction decreased; however, the significance value remained the same ( $\left.\mathrm{c}^{\prime}=-.06, \mathrm{SH}=.02, \mathrm{t}=-4.12, \mathrm{p}<.001\right)$. According to this result, psychological flexibility plays a mediating role between alexithymia and life satisfaction. In this way, the second hypothesis of the study is that there is an indirect and negative effect on the relationship between the alexithymia levels of individuals and their life satisfaction through psychological flexibility.

Taking the abovementioned findings into consideration, it can be said that individuals, who do not show alexithymic features, are psychologically more flexible; therefore, their life satisfaction increases. Individuals, who are aware of their emotions and can express them, are more flexible (Cassar, Knowles, Youssef, Moulding, Uiterwijk, Waters \& Austin, 2018), and flexible individuals have higher life satisfaction (Graham, Gouick, Ferreira \& Gillanders 2016; Harris, 2016, Kemerli \& Çelik, 2015; Seyrek \& Ersanl1, 2017). The results of Wersebe, Lieb, Meyer, Hofer \& Gloster (2018) also support the results of the research. In addition, it can be said that individuals with low psychological flexibility have higher levels of depression (Richardson \& Jost, 2019), anxiety (Berryhill, Hayes \& Lloyd 2018; Chong, Mak \& Loke 2017) and stress (Flynn \& Rudolph, 2016), so their life satisfaction will be lower. This finding is consistent with the finding in the study that there is a positive relationship between psychological flexibility and life satisfaction.

In that sense, it can be concluded that if individuals with low levels of alexithymia increase psychological flexibility, their life satisfaction increases. The result of this research supports the work of Atasayar (2011), Nekouei, Neshat-Doost, Yousefy, Manshaee, \& Sadeghei (2014), and Yilmaz (2017). However, there are studies that do not support this result and assert that there is no relationship between alexithymia and life satisfaction (Duysak, 2011; İşleroğlu, 2012; Kuzucu, 2006). There are also studies on the components of alexithymia: emotional awareness versus depression (Uslu \& Gizir, 2019; Van Beveren et al., 2019), emotional awareness versus anxiety (Sendzik, Schäfer, Samson, Naumann \& Tuschen-Caffier, 2017), and expressing emotions versus stress (Lepore, Ragan \& Jones, 2000). It can be said that these results support the research result. Since alexithymic individuals may be depressed, intensely stressed and anxious, they may not be satisfied with life.

While the direct effect of alexithymia on life satisfaction is $c=-.13$, its effect on authenticity through psychological flexibility is $c^{\prime}=-.06$ '. Therefore, it can be said that the impact coefficient has decreased, but the level of significance remains the same as .000 . Thus, it can also be claimed that psychological flexibility plays a partial mediating role in the relationship between alexithymia and life satisfaction, in line with the opinion of Baron and Kenny (1986). Since it is a partial mediation, it can be said that it may affect the relationship between alexithymia and life satisfaction in variables other than psychological flexibility. For the model of the mediating role of psychological flexibility in the relationship between alexithymia and life satisfaction, the Sobel test result is $\mathrm{Z}=-7.3386 ; \mathrm{p}=.000$. This finding illustrates the fact that the mediator variable is significant ( $p$ <.001). When the findings of Preacher and Hayes (2008) and their BootLLCI and BootULCI values were examined according to the bootstrap model, it was confirmed that there was no " 0 " between them. 
The following suggestions can be made related to the findings of the study:

\section{Suggestions for Implementation}

Considering the effect of alexithymia on psychological flexibility, life satisfaction and authenticity, interviews, seminars, panels can be organized. In addition, brochures prepared on this subject can be distributed to reduce the alexithymia levels of individuals. In particular, psycho-education programs can be applied to enable individuals to recognize their emotions and teach ways of expressing them. Adults might be given training about emotional awareness, expressing emotions and psychological flexibility, and social activities can be organized accordingly. If conscious parents raise children in this way, their life satisfaction can increase in their adulthood, and they can lead a more authentic life. Counseling sessions for individuals to recognize and express their emotions and to be psychologically flexible can be held. As a further remark, training programs can be applied to increase the emotional awareness and expressing skills of individuals in all education periods.

\section{Implications for the Future Studies}

As for future directions of research it can be accentuated that comprehensive studies can be conducted in which different variables such as self-esteem and parental attitudes that may be related to authenticity and life satisfaction variables are independent or mediating variables. In this way, more variance results can be obtained to explain the phenomena in detail. Since alexithymia includes the concepts of emotional awareness and expressing emotions, these concepts can be considered separately, and the scope of the study can be expanded with different measurement tools. As a study group, the sample can be expanded by working with groups such as adolescents or university students, and the results can be discussed longitudinally. The present research is the first research that examines the relationships among these four variables, and since it is a survey, experimental or qualitative research can be done on these variables. In this way, cause-effect relationships can be discussed in more detail. Studies can be repeated by using different scales regarding the variables of the study. Different research models can be developed by finding other variables that affect authenticity and life satisfaction. Due to the fact that the scales used in the study are based on self-assessment, social acceptance error may occur. In order to overcome this, techniques such as interview and observation can be used to obtain information about the person from the individuals' immediate environment such as family or friends.

\section{Acknowledgements}

This study is a part of the postgraduate study conducted by Sena Karakuş at Mersin University Institute of Educational Sciences under the supervision of Sinem Evin Akbay.

\section{References}

Akbay, S. E. (2015). Ana-babaya bağlanma ile romantik yakınlık ve otantik benlik arasındaki ilişkilerde bağlanma stillerinin aracı rolünün incelenmesi [An investigation of the relations between parental bonding with intimacy and authentic self in mediated by attachment style]. (Doctoral thesis). Mersin Üniversitesi [University of Mersin], Mersin.

Aktepe, M. (2016). Bipolar bozukluk hastalarında psikolojik esneklik [Psychological flexibility in bipolar disorder patients]. (Medical Specialty Thesis), Bakırköy Eğitim ve Araştırma Hastanesi [Bakırköy Training and Research Hospital], İstanbul. 
Albal, E. (2019). Madde bağımlılarında şema ve psikolojik esneklik yaklaşımlarının madde bağımlılı̆̆ şiddetine etkisi [The effect of schemas and psychological flexibility approaches on the addiction severity of drug addicts]. (Doctoral thesis). İstanbul Üniversitesi Cerrahpaşa Lisansüstü Eğitim Enstitüsü [Istanbul University Cerrahpasa Graduate Education Institute]. İstanbul.

Atasayar, M. (2011). Ergenlerin aleksitimik özelliklerinin psikolojik belirtileri ve yaşam doyumlart ile ilişkisi [The Alexithymic Characteristics of Adolescent' The Relationship with Psychological Symptoms and Life Satisfaction]. (Master's thesis). Sakarya University, Sakarya.

Bagby, R.M., Taylor, G.J. \& Parker, J.D.A. (1994). The twenty-item Toronto Alexithymia Scale: II. Convergent, discriminant, and concurrent validity. J Psychosom Res, 38, 3340.

Baron, R. M. \& Kenny, D. A. (1986). The moderator-mediator variable distinction in social psychological research: Conceptual, strategic, and statistical considerations. Journal of Personality and Social Psychology, 51(6), 1173-1182.

Beck, J. (2001). Cognitive Behavior Therapy. Ankara: Turkish Psychological Association

Berryhill, M. B., Hayes, A. \& Lloyd, K. (2018). Chaotic-enmeshment and anxiety: the mediating role of psychological flexibility and self-compassion. Contemporary Family Therapy, 40(4), 326-337.

Brunell, A. B., Kernis, M. H., Goldman, B. M., Heppner, W., Davis, P., Cascio, E. V. \& Webster, G. D. (2010). Dispositional authenticity and romantic relationship functioning. Personality and Individual Differences, 48(8), 900-905.

Büyüköztürk, Ş. (2015). Sosyal bilimler için veri analizi el kitabı [Data analysis Handbookfor social Sciences]. Ankara: Pegem Yayınc1lkk [Pegem publishing].

Cassar, G. E., Knowles, S., Youssef, G. J., Moulding, R., Uiterwijk, D., Waters, L. \& Austin, D. W. (2018). Examining the mediational role of psychological flexibility, pain catastrophizing, and visceral sensitivity in the relationship between psychological distress, irritable bowel symptom frequency, and quality of life. Psychology, Health \& Medicine, 23(10), 1168-1181.

Chong, Y. Y., Mak, Y. W. \& Loke, A. Y. (2017). Psychological flexibility in parents of children with asthma: analysis using a structural equation model. Journal of Child and Family Studies, 26(9), 2610-2622.

Cüceloğlu, D. (2005). Başartya götüren aile [Family leading to success].İstanbul: Remzi Yayınevi [Remzi publishing].

Çeçen, H., (2015). Panik bozukluk hastalarında aleksitimi, anksiyete duyarlılı̆̆l, sirkadiyen tercihler ve biyokimyasal ölçümlerin değerlendirilmesi [The evaluation of alexithymia, anxiety sensitivity, circadian preferences and some biochemical alterations in the panic disorder patients]. (Medical Specialty Thesis),Yüzüncü Yıl Üniversitesi Tıp Fakültesi [Yüzüncü Y1l University Faculty of Medicine], Van.

Dağlı, A. \& Baysal, N. (2016). Yaşam Doyumu Ölçeğinin Türkçeye uyarlanması: geçerlik ve güvenirlik çalışması [Adaptation of Life Satisfaction Scale to Turkish: A Validity and Reliability Study]. Elektronik Sosyal Bilimler Dergisi [Electronic Journal of Social Sciences], 15(59), 1250-1262.

Denckla, C. A., Consedine, N. S., Chung, W. J., Stein, M., Roche, M. \& Blais, M. (2018). A double-edged sword? Sub-types of psychological flexibility are associated with distinct psychiatric disorders. Journal of Research in Personality, 77, 119-125.

Diener, E., Emmons, R. A., Larsen, R. J. \& Griffin, S. (1985). The satisfaction with life scale. Journal of Personality Assessment, 49(1), 71-75. 
Dökmen, Ü. (2000). Sanatta ve Günlük Yaşamda Iletişim Çatışmaları ve Empati [Communication Conflicts and Empathy in Art and Daily Life]. İstanbul: Sistem Yayıncılik [Sistem Publishing].

Duysak, S. (2011). Psoriazisli hastalarda kişilik özellikleri ve aleksitiminin yaşam kalitesiyle iliskisi [The relation of personality traits and alexithymia with quality of life in patients with psoriasis]. (Medical Specialty Thesis). Zonguldak Karaelmas Üniversitesi T1p Fakültesi Hastanesi [Zonguldak Karaelmas University Medical Faculty Hospital], Zonguldak.

Feldman-Barrett, L., Gross, J., Corner-Christensen, T. \& Benvenuto, M. (2001). Knowing what you're feeling and knowing what to do about it: mapping the relation between emotion differentiation and emotion regulation. Cognition and Emotion, 15, 713-724.

Fledderus, M., Bohlmeijer, E. T., Smit, F. \& Westerhof, G. J. (2010). Mental health promotion as a new goal in public mental health care: A randomized controlled trial of an intervention enhancing psychological flexibility. American Journal of Public Health, $100(12), 2372-2372$.

Flynn, M. \& Rudolph, K.D. (2010) The contribution of deficits in emotional clarity to stress responses and depression. Journal of Applied Developmental Psychology. 31, 291-297.

Francis, A.W., Dawson, D. L. \& Golijani-Moghaddam, N. (2016). The development and validation of the Comprehensive assessment of Acceptance and Commitment Therapy processes (CompACT). Journal of Contextual Behavioral Science, 5, 134.145.

Frijda, N.H. (2008). The psychologists point of view. In a L. Michael, H. Jones J. M. Barrett (Ed.). Handbook of emotion (Third Edition). London: Guilford Pres.

Fujimura, T. \& Okanoya, K. (2012). Heart rate variability predicts emotional flexibility in response to positive stimuli. Psycho-Logy. 3(8), 578-582.

Graham, C.D., Gouick, J., Ferreira, N. \& Gillanders, D. (2016). The influence of psychological flexibility on life satisfaction and mood in muscle disorders. Rehabilitation Psychology, 61(2), 210-217.

Gratz, K. L. \& Roemer, L. (2004). Multidi-mensional assessment of emotion regulation and dysregulation: development, factor structure, and initial validation of the difficulties in emotion regulation scale. Journal of Psychopathology and Be-Havioral Assessment, 26(1), 41-54.

Greenberg, L. S. (2006). Emotion in psychotherapy: A practice-friendly research review. Journal of Clinical Psychology, 62(5), 611-630.

Guilford, J. P. (1954). Psychometric methods. New York, NY: McGraw-Hill.

Güleç, H., Köse, S., Güleç, M.Y., Çitak, S., Evren, C., Borckardt, J. \& Sayar, K. (2009). Reliability and factorial validity of the turkish version of the 20-1tem Toronto Alexithymia Scale (TAS-20). [Bulletin of Clinical Psychopharmacology], 19(3), 214220.

Gün, N. (2007). İçimizdeki zaman, duyguların simyası [Time inside us, alchemy of emotions], İstanbul: Kuraldışı Yayınları [Kuraldısı Publishing].

Harris, R. (2016). Easy to Learn ACT. İstanbul: Litera Yayınc1lık [Litera Publishing].

Harter, S. (2002). Authenticity. In a C. R. Snyder \& S. J. Lopez, Handbook of Positive Psychology (pp. 382-394). New York: Oxford University Press.

Heppner, W. L., Kernis, M. H. Nezlek, J. B. Foster, J., Lakey, C. E. \& Goldman, B. M. (2008). Within person relationships among daily self esteem, need satisfaction, and authenticity. Psychological Science, 19, 1140-1145.

İlhan, T. \& Özdemir, Y. (2013). Otantiklik ölçeğinin Türkçe’ye uyarlanması: Geçerlik ve güvenirlik çalışması [Adaptation of the authenticity scale to Turkish: Validity and reliability study]. Türk Psikolojik Danışma ve Rehberlik Dergisi [Turkish Journal of Psychological Counseling And Guidance], 5(40), 142-153. 
İşleroğlu, S. (2012). Lise ögrencilerinde öznel iyi oluşun benlik saygısı, sosyal yetkinlik beklentisi ve duygulart ifade etme eğilimine göre yordanması [Predicting subjective well-being among high school students according to self-esteem, social self efficacy, and tendency to express of emotions]. (Masters' thesis). Ege University, İzmir.

Karakuş, S. \& Akbay, S. E. (2020). Psikolojik esneklik ölçeği: uyarlama, geçerlik ve güvenirlik çalışması. çalışması [Adaptation of the pshycological flexibility scale to Turkish: Validity and reliability study]. Mersin University Journal of the Faculty of Education, 16(1), 32-43.

Karasar, N. (2005). Bilimsel araştırma yöntemi [Scientific research method]. Ankara: Nobel Kitabevi [Nobel Publishing]..

Kemerli, B. \& Çelik, T. (2015). Aleksitimi ölçeğinin geçerlik ve güvenirliği çalışması [Alexitiymia scale: Validity and reliability study]. Journal of European Education, 2, 38-46.

Kernis, M.H., \& Goldman, B.M. (2006). A multicomponent conceptualization of authenticity: Theory and Research. Advances in Experimental Psychology, 38, 283-356.

Koçak, R. (2002). Aleksitimi: kuramsal çerçeve tedavi yaklaşımları ve ilgili araştırmalar [Alexithymia: theoretical framework treatment approaches and related research]. Ankara Üniversitesi Eğitim Bilimleri Fakültesi Dergisi [Ankara University Journal of Faculty of Educational Sciences]. 35 (1-2), 183-212.

Kuyumcu, B. \& Kabasakaloğlu, A. (2018). Otantik Olmanın Duyuşsal İyi Oluşu (PozitifNegatif Duygu Durumu) Yordama Gücü: Türk ve İngiliz Üniversite Öğrencileri Arasında Otantik Olma ve Pozitif-Negatif Duygu Durumu [The Predictive Power of Authenticity on Emotional Well-being Positive-Negative Affect : Authenticity and Positive-Negative Affect among Turkish and English University Students]. Yüksekögretim ve Bilim Dergisi [Journal of Higher Education \& Science]. 8 (1), 184-193.

Kuzucu, Y. (2006). Duygularl fark etmeye ve ifade etmeye yönelik bir psikoeğitim programinın, üniversite ögrrencilerinin duygusal farkındalı düzeylerine, duyguları ifade etme eğilimlerine, psikolojik ve öznel iyi oluşlarına etkisi [The effects of psycho-education program of emotional awareness and expression on levels of emotional awareness, tendency to express of emotions, psychological well-being and subjective well-being]. (Doctoral thesis), Ankara Üniversitesi [University of Ankara]. Ankara.

Leahy, R. L. (2006). Emotional schemas and resistance to change in anxiety disorders, Cognitive and Behavioral Practice, 14 (1), 36-45.

Lepore, S. J., Ragan, J. \& Jones, S. (2000). Talking facilitates cognitive- emotional processes of adaptation to an acute stressor. Journal of Personality and Social Psychology, 78, 499-509.

Lopez, F. G. \& Rice, G. K. (2006). Preliminary development and validation of a measure of relationship authenticity. Journal of Counseling Psychology, 53, 362-371.

Myers, J. E., Sweeney, T. J. \& Witmer, J. M. (2000). The wheel of wellness counseling for wellness: A holistic model for treatment planning. Journal of Counseling \& Development, 78(3), 251-266.

Neff, K. D. \& Suizzo, M.-A. (2006). Culture, power, authenticity and psychological wellbeing within romantic relationships: A comparison of European American and Mexican Americans. Cognitive Development, 21(4), 441-457.

Nekouei, Z.K., Neshat-Doost, H.T., Yousefy, A., Manshaee, G. \& Sadeghei, M. (2014). The relationship of alexithymia with anxiety-depression-stress, quality of life, and social support in Coronary Heart Disease (A psychological model). Journal of Education and Health Promotion, 3 (68), 98-105.

Özen, Ş., Bez ,Y., Arı, M. \& Özkan, M. (2010). Öfke kontrolünde zorluk yaşayan bir grup üniversite ögrencisinde öfke tepkileri ve psikiyatrik tanıların cinsiyet açısından 
incelenmesi [Examination of anger reactions and psychiatric diagnoses in terms of gender in a group of university students having difficulty with anger control]. Türk Psikiyatri Dergisi [Turkish Journal of Psychiatry], 21(4), 319-30.

Preacher, K. J., \& Hayes, A. F. (2008). Asymptotic and resampling strategies for assessing and comparing indirect effects in multiple mediator models. Behavior Research Methods, 40, 879-891.

Richardson, C. M. \& Jost, S. A. (2019). Psychological flexibility as a mediator of the association between early life trauma and psychological symptoms. Personality and Individual Differences, 141, 101-106.

Sendzik, L., Schäfer, J. Ö., Samson, AC, Naumann, E. \& Tuschen-Caffier, B. (2017). Emotional awareness in depressive and anxiety symptoms in youth: A meta-analytic review. Journal of Youth and Adolescence, 46 (4), 687-700.

Seyrek, Ö. D. \& Ersanlı, K. (2017). Üniversite öğrencilerinde yaşamın anlamı ile psikolojik esneklik arasındaki ilişki [The relationship between meaning in life and psychological flexibility of university students]. Electronic Turkish Studies, 12(4), 143-162.

Swinkels, A. \& Giuliano, T. A. (1995). The measurement and conceptualization of mood awareness: monitoring and labeling one's mood states. Personality and Social Psychology Bulletin, 21(9), 934- 949.

Tabachnick, B.G. \& Fidell, L.S. (2013). Using Multivariate Statistics. Pearson, Boston

Takma, Ç. \& Atıl, H., (2006), Bootstrap Metodu ve Uygulanışı Üzerine Bir Çalışma 2. Güven Aralıklarl, Hipotez Testi ve Regresyon Analizinde Bootstrap Metodu [A Study on Bootstrap Method and It's Application II. Confidence Interval, Hypothesis Testing and Regression Analysis with Bootstrap Method], Ege Üniversitesi Ziraat Fakültesi Dergisi [Journal of Agriculture Faculty of Ege University], 43(2), 63-72.

Tarhan, N. (2009). Duyguların dili [Language of emotions]. İstanbul: Timaş Yayınları [Timas Publishing].

Togay, A. (2016). Evli bireylerin kendini saklama ĕgilimi, öfke ifade tarzl ve otantiklikleri arasindaki ilişkiler [Relations between self concealment, anger expression style and authenticity in married persons]. (Masters' thesis). Hacettepe University, Ankara.

Uslu, Y. \& Gizir, C. A. (2019). Duygusal farkındalık boyutlarının üniversite öğrencileri benlik saygısı, sosyal kaygı ve depresyon düzeyleri üzerinde yordayıcı rolü [The Predictive Role of Emotional Awareness Dimensions on Self-Esteem, Social Anxiety and Depression Levels of University Students]. İönü Üniversitesi Eğitim Fakültesi Dergisi [İnönü University Journal of the Faculty of Education], 20 (3), 876-890.

Uygur, S. S. (2018). Üniversite öğrencilerinin psikolojik esneklik düzeylerinin yordanmasında duygusal şemaların rolü: Buca Eğitim Fakültesi Örneği [The role of emotional schemes in predicting psychological flexibility levels of university students the example of faculty of Buca Education]. The Journal of Academic Social Science Studies, 70, 135151.

Van Beveren, M. L., Goossens, L., Volkaert, B., Grassmann, C., Wante, L., Vandeweghe, L. \& Braet, C. (2019). How do I feel right now? Emotional awareness, emotion regulation, and depressive symptoms in youth. European child \& adolescent psychiatry, 28(3), 389-398.

Wersebe, H., Lieb, R., Meyer, A. H., Hofer, P. \& Gloster, A. T. (2018). The link between stress, well-being, and psychological flexibility during an Acceptance and Commitment Therapy self-help intervention. International Journal of Clinical and Health Psychology, 18(1), 60-68.

Wong, P. T. (2010). What is existential positive psychology? International Journal of Existential Psychology \& Psychotherapy, 3(1), 1-10. 
Wood, A. M., Linley, P. A., Maltby, J., Baliousis, M. \& Joseph, S. (2008). The authentic personality: A theorical and empirical conceptualization and the development authenticity scale. Journal of Counseling Psychology, 55, 385-399.

Yalçın, S. B. (2010). Üniversite ögrencilerinin duygulart ifade edebilmelerinin aleksitimi ve psikolojik ihtiyaçlarına göre incelenmesi [Analysing the ability of university students in expressing their emotions in terms of alexithymia and psychological necessities]. (Unpublished doctoral thesis). Selçuk University Konya.

Yavuzer, N. (2000). Illetişim ve etkili yaşam kültürü, çocuklarımız için eğitim sohbetleri [Communication and effective life culture, educational conversations for our children]. Ankara: Pegem A Yayıncilik [Pegem A Publishing].

Yıldırım, Ş. (2017). Görücü usulü evlenen ve flört ederek evlenen çiftlerin duygusal farkındalık ve duygularl ifade etme düzeylerinin evlilik doyumuna etkisi [The effect of emotioanl awareness and expression level of the couples who got married after flirting or via blind date on marrital satisfaction]. (Master thesis), Beykent University, İstanbul.

Yılmaz, Ö. (2017). Yetişkinlerde anormal hastalık davranışları ve yaşam kalitesi ile ilişkili faktörler: sağlık kaygısı, kaygı duyarlılı̆̆ı, sağlıkla ilgili işlevsel olmayan inançlar ve aleksitimi [Factors associated with abnormal illness behaviors and quality of life in adults: Health anxiety, anxiety sensitivity, health related dysfunctional beliefs and alexithymia]. (Masters' thesis). Dokuz Eylül University, İzmir

Yılmaz, V. \& İlhan Dalbudak, Z. (2018). Aracı değişken etkisinin incelenmesi: yüksek hızlı tren işletmeciliği üzerine bir uygulama. [Research of the effect of mediation variable: an application of the management of high-speed train]. Uluslararası Yönetim İktisat ve Işletme Dergisi [Int. Journal of Management Economics and Business], 14(2), 517534. 